\title{
PERANCANGAN SISTEM MONITORING PERANGKAT ELEKTRONIK RUMAH MENGGUNAKAN INTERNET
}

\author{
Dias Prihatmoko \\ Program Studi Teknik Elektro, Fakultas Sains dan Teknologi \\ UNISNU Jepara \\ Email: diasprihatmoko@unisnu.ac.id
}

\begin{abstract}
ABSTRAK
Penghematan energi pada rumah bila dilaksanakan secara sistematis akan berpotensi mengurangi konsumsi energi yang besar, tetapi pada prakteknya program hemat energi tersebut belum maksimal. Perangkat elektronik rumah sering menyala sampai pagi, kondisi ini akan menyebabkan pemborosan energi listrik apabila terjadi berulang-ulang. Oleh karena itu, perlu adanya sistem kontrol dan monitor perangkat elektronik rumah yang praktis dan efisien. Penelitian ini mengajukan perancangan sistem otomatisasi rumah menggunakan internet yang dapat secara otomatis mengontrol dan memonitor keadaan rumah dari jarak jauh. Perancangan ini berupa perancangan perangkat keras dan perangkat lunak menggunakan bahasa pemrograman berbasis android, Bahasa Pemrograman C, dan database. Hasil dari penelitian ini adalah sistem otomatisasi rumah yang dapat digunakan untuk kontrol dan monitor perangkat elektronik rumah dengan rata-rata waktu respon 1,26 detik.
\end{abstract}

Kata kunci: sistem otomatisasi rumah; monitoring dan kontrol dengan internet; perangkat elektronik rumah.

\begin{abstract}
Good home energy savings will potentially reduce large energy consumption, but in practice energy saving is not good. Home electronics devices are often ON until morning, this condition will lead to wasteful electrical energy. Therefore, it is necessary to control and monitor electronic home appliance system is good and efficient. This research proposes the design of home automation system using the internet that can automatically control and monitor the state of the house remotely. The design is hardware and software using android based programming language, C Programming Language, and database. The results of this study are home automation systems that can be used for control and monitor home electronic devices with an average response time of 1.26 seconds.
\end{abstract}

Keyword: home automation; monitoring and control with internet; home electronic devices.

\section{PENDAHULUAN}

Kebutuhan energi listrik nasional terus meningkat. Hal tersebut dikarenakan pemakaian listrik yang besar pada rumah, gedung, maupun industri. Di sisi lain, pemakaian energi listrik untuk skala rumah tangga juga sangat boros. Hal ini disebabkan karena kurang memperhatikan besar kecilnya daya (watt) perangkat elektronik yang digunakan. Kondisi tersebut akan berimbas pada sektor rumah, gedung maupun industri yang energi listriknya menggunakan PLN. Permasalahan tersebut harus ditanggapi serius oleh pengelola untuk menekan pemakaian energinya. Salah satu cara yang paling mudah adalah dengan memanfaatkan energi secara maksimal melalui program hemat energi.

Hemat energi merupakan suatu cara pemanfaatan energi secara rasional dan efisien tanpa mengurangi penggunaaan energi yang memang benar-benar diperlukan. Penghematan energi pada rumah bila dilaksanakan secara sistematis akan berpotensi mengurangi konsumsi energi yang besar. Akan tetapi pada prakteknya program hemat energi tersebut masih belum maksimal. Salah satu masalah yang dihadapi dalam melakukan penghematan energi adalah sistem pengontrolan perangkat elektronik pada rumah saat ini masih tergolong konvensional yaitu dengan menggunakan saklar atau relatif hanya menggunakan prinsip pengontrolan jarak dekat (manual), sehingga untuk menghidupkan dan mematikan perangkat elektronik harus dengan mendekati saklar terlebih dulu.

Sering kali lampu dan perangkat elektronik di rumah-rumah tetap menyala sampai pagi, bahkan kadang-kadang sampai menginjak hari berikutnya, hal ini banyak disebabkan karena kelalaian pemilik rumah dalam mematikan lampu dan perangkat elektroniknya, apalagi jika rumah tersebut ditinggal oleh pemiliknya selama beberapa hari, maka kondisi seperti ini akan menyebabkan pemborosan energi listrik apabila terjadi berulang-ulang. Oleh karena itu perlu adanya sistem kontrol dan monitor perangkat elektronik pada rumah yang lebih baik. 
Dengan berkembangnya internet of things [1][2] maka kontrol perangkat elektronik yang ada didalam rumah dapat dilakukan dengan menggunakan internet dan juga smartphone yang terhubung dengan internet, sehingga pengontrolan dan monitoring bisa dilakukan dimana saja[3][4][5][6].

Beberapa usaha dan penelitian sebelumnya telah banyak dilakukan, diantaranya, penelitian yang dilakukan oleh Carelin Felix and Jacob. R, dengan judul Home automation Using GSM, membuat sistem pemantauan jarak jauh keadaan rumah menggunakan teknologi GSM [7]. Mikrokontroller yang digunakan adalah PIC (Peripheral Interface Controller) sedangkan untuk kontrol jarak jauh digunakan ponsel berteknologi GSM dengan cara mengirimkan SMS ke server lalu diterjemahkan oleh kontroller dan diteruskan ke saklar on off di perangkat listrik rumah. Ponsel GSM harus memiliki sinyal yang cukup supaya dapat berkomunikasi antara transmitter dan receiver. Penelitian berikutnya yang dilakukan oleh R.Piyare and M.Tazil, dengan judul Bluetooth Based Home automation System Using Cell Phone [8], tentang desain dan implementasi sistem home automation menggunakan ponsel dengan biaya terjangkau tetapi belum fleksibel dan tidak memperhatikan faktor keamanan. Mikrokontroller yang digunakan adalah arduino yang terhubung ke perangkat listrik dirumah melalui relay. Komunikasi antar ponsel menggunakan komunikasi tanpa kabel yaitu secara ad hoc. Sistem ini juga dilengkapi dengan sistem proteksi berupa password yang memungkinkan hanya pihak pengguna saja yang bisa mendapat hak akses dari sistem tersebut dan untuk komunikasi dengan arduino digunakan bluetooth. Sistem pengontrolannya menggunakan perintah kode ascii melalui port serial, kemudian diterjemahkan menjadi biner oleh arduino. Sistem ini terbatas pada jarak untuk mengontrol perangkat listrik, karena menggunakan komunikasi ad hoc jadi hanya berjarak sekitar 50 meter didalam gedung dan sekitar 100 meter jika di luar ruangan. Selain dari itu, sistem belum dilengkapi dengan GUI sehingga hanya bisa melakukan pengontrolan saja dan tidak untuk monitoring.

Sedangkan penelitian yang dilakukan oleh Iyuditya and Erlina Dayanti, dengan judul Sistem Pengendali Lampu Ruangan Secara Otomatis Menggunakan Pc Berbasis Mikrokontroler Arduino Uno [9], membuat pengendalian yang secara otomatis untuk mengendalikan nyala dan padamnya lampu yang dijembatani oleh sebuah mikrokontroller sebagai interface. Hasilnya, minat dan respon dalam menggunakan sistem pengendalian lampu ini masuk ke dalam kategori berminat. Hal ini menunjukan bahwa dengan adanya sistem baru yang dibuat dapat membantu mengendalikan lampu otomatis dengan 42 responden. Berdasarkan tabel prosentase dapat menunjukkan bagaimana efektifitas pengunaan dalam proses pengendalian dan efisiensi, dan respon presentase adalah 78,5\% dengan nilai Cronbach's Alpha hasil uji SPSS sebesar 0,718. Selanjutnya penelitian yang dilakukan oleh Sri Supatmi,Taufiq Nuzwir Nizar,and Reza Fahlevi, dengan judul Sistem Kontrol Peralatan Rumah dan Monitoring Kondisi Rumah Melalui Internet Berbasis Web dan OpenWRT [10], menggunakan perangkat access point TL-MR3020 sebagai servernya / pengganti PC server dirumah. Sistem informasi yang digunakan adalah sistem informasi berbasis web. Perangkat lunak yang digunakan adalah linux openWRT yang di install di server. Hasil dari penelitian ini adalah berupa sistem pengontrolan perangkat elektronik rumah menggunakan web melalui smartphone atau komputer dari jarak jauh. Data hasil pengontrolan akan dikirim melalui email pengguna.

Melihat perkembangan tersebut timbul gagasan untuk membuat sebuah sistem otomatisasi perangkat elektronik rumah yang dapat diakses dari jarak jauh dengan memanfaatkan jaringan internet. Sistem Monitoring dan Controlling yang akan dilakukan adalah dengan menggunakan OpenHAB (Open Home automation Bus), OpenHAB tersebut berfungsi untuk menghubungkan peralatan elektronik rumah dengan internet menggunakan sistem operasi open source. Sistem bisa dibahas otomatis dan juga manual melalui internet serta dilengkapi dengan penjadwalan waktu kapan perangkat elektronik rumah harus menyala dan padam, User interface yang lebih frendly akan memudahkan pengguna dalam menggunakan aplikasi tersebut, serta dilengkapi dengan sistem pengendalian jarak jauh HVAC ( Heating, Ventilation and Air Conditioning ) yang akan membuat pengguna merasa nyaman berada di dalam rumah. Untuk sistem informasi yang digunakan berupa sistem informasi multiplatform dan sistem informasi berbasis android.

Sedangkan untuk perangkat keras yang digunakan adalah perangkat Raspberry Pi sebagai servernya yang berfungsi sebagai perantara komunikasi antara internet dan perangkat elektronik rumah. Dengan sistem otomatisasi seperti ini maka kelalaian dalam pemadaman perangkat elektronik akan dapat di hindari sehingga penghematan energi listrik dalam rangka gerakan mengurangi global warming juga akan terwujud. 


\section{METODE PENELITIAN}

Langkah penelitian ini diawali dengan kegiatan tinjauan pustaka dan studi literatur, dengan adanya tinjauan pustaka tersebut berfungsi untuk mencari referensi-refensi yang sejalan dengan tema dan pokok bahasan dalam penelitian ini. Setelah kegiatan ini selanjutnya adalah langkah identifikasi masalah, fungsinya adalah untuk mengidentifikasi permasalahan dalam penelitian ini. Setelah di identifikasi permasalahan tersebut maka selanjutnya dilakukan perancangan sistem dengan memperhatikan dari tinjauan pustaka dan identifikasi masalah sebelumnya serta metode maupun langkah-langkah yang sejalan dengan tema penelitian ini. Beberapa kajian perancangan terkait dengan : (1) perancangan arsitektur sistem raspberry beserta sensor suhu dan sensor cahaya, (2) peralatan yang dipakai dalam perancangan. Selanjutnya yang dilakukan adalah perancangan sistem berdasar masalah yang muncul pada bagian identifikasi masalah.

Hasil dari perancangan sistem berupa prototype yang masih belum stabil serta masih memerlukan pengujian agar dapat mengoptimalkan kinerja sistem secara keseluruhan. Selanjutnya pengujian dilakukan pada bagian - bagian yang sangat penting, diantaranya sebagai berikut : (1) Sistem arsitektur sistem otomatisasi beserta sensor suhu dan sensor cahayanya, (2) Sistem manajemen monitor serta kontrol perangkat elektronik menggunakan android. Pengujian dilakukan sampai dicapai hasil yang terbaik berdasar hasil pengujian serta analisis sistem. Pengujian serta analisis tersebut nantinya menghasilkan prototype yang lebih stabil secara keseluruhan.

Langkah - langkah penelitian untuk menyelesaian permasalahan dalam penelitian ini. ditampilkan pada gambar 1 :

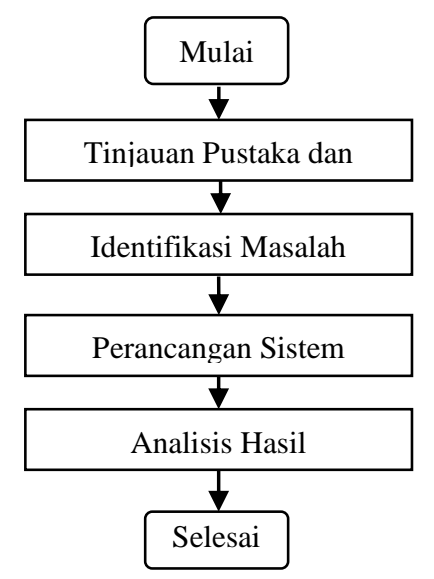

Gambar 1. Tahapan Penelitian

Untuk merancang serta menerapkan sistem ini dibuat dari beberapa perangkat keras diantaranya(1). Raspberri Pi, (2). Arduino Uno Rev 3, (3). Sensor Suhu, dan Cahaya. Adapun perangkat lunaknya terdiri dari :(1). OS Raspbain, (2). Apache, (3). MySQL, (4). ARDUINO_IDE, (5). Notepad ++

Perancangan perangkat lunak dan perangkat keras dilakukan untuk membuat sistem secara keseluruhan yang terdiri dari beberapa blok perangkat diantaranya yaitu User, Server Gateway, Internet, mikrokontroller, Rangkaian Sensor dan Perangkat Elektronik.

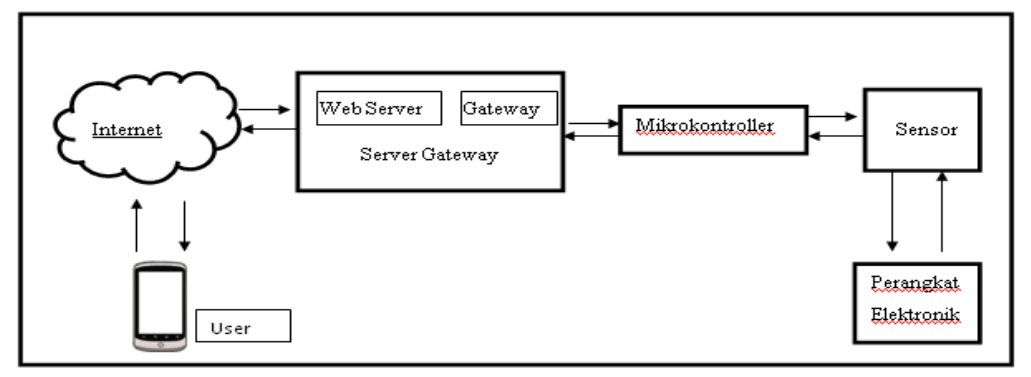

Gambar 2. Bagan Sistem Otomatisasi Rumah

Prinsip kerja dari blok diagram sistem otomatisasi rumah diatas adalah yang dalam hal ini User dapat diartikan sebagai pengguna. Pengguna dapat secara jauh memonitor dan mengontrol sistem otomatisasi rumah dengan menggunakan HP android. Sistem komunikasinya dengan menggunakan 
internet. Pengguna dapat melakukan kontrol secara manual dengan cara melakukan aksi ON atau OFF perangkat elektronik rumah dan juga sistem dapat bekerja secara otomatis menggunakan sensor. Selanjutnya pengguna juga dapat melakukan monitor keadaan rumah secara real time menggunakan perangkat HP android dari jarak jauh. Adapun proses komunikasi dari sistem tersebut adalah dapat menggunakan sistem komunikasi dua arah. Sistem dapat mengirimkan data dan juga dapat menerima data.

Saat pengguna mengirimkan perintah ON atau OFF maka sistem mengirim data ke database melalui Server Gateway. Setelah data diterima maka akan dikirimkan ke mikrokontroller untuk diproses dan dikirimkan ke perangkat elektronik. Setelah itu maka akan dieksekusi sesuai dengan perintah pengguna. Selanjutnya setelah perangkat elektronik melakukan aksi sesuai dengan perintah pengguna maka mikrokontroller akan kembali mengirimkan data ke Server Gateway sebagai bentuk konfirmasi bahwa perintah tersebut telah dilaksanakan, kemudian disimpan ke database untuk perubahan status perangkat elektronik rumah.

Sistem juga dapat berjalan secara otomatis dengan menggunakan sensor. Adapun sensor yang digunakan dalam tema penelitian ini adalah sensor suhu dan sensor cahaya. Fungsinya adalah mengukur nilai suhu dan nilai intensitas cahaya yang kemudian dilakukan otomatisasi dengan parameter nilai suhu dan intensitas cahaya yang sudah di tentukan sebelumnya. Jika nilai suhu dan intensitas cahaya melewati batas - batas yang sudah ditentukan maka mikrokontroller akan mengeksekusinya sesuai dengan perintah yang telah diprogramkan di dalam mikrokontroller. Jika di dapat perubahan aksi perangkat elektronik maka mikrokontroller akan mengirimkan data ke database untuk dilakukan perubahan status perangkat elektronik pada perangkat antar muka pengguna.

\section{HASIL DAN PEMBAHASAN}

Setelah dilakukan perancangan maka langkah selanjutnya adalah melakukan pengujian untuk mendapatkan hasil yang lebih baik. Pengujian ini dilakukan dalam 2 tahap yaitu (1). Pengujian Kontrol Perangkat Elektronik.(2). Pengujian Waktu Respon. (3).Pengujian Sensor.

Pengujian pertama yang dilakukan adalah Pengujian Kontrol Perangkat Elektronik, hal ini dimaksudkan untuk mengetahui apakah sistem kontrol benar - benar berjalan atau tidak. Terdapat 3 buah button Matikan dan Hidupkan pada halaman kontrol. Apabila button Matikan di klik maka User interface akan mengirim perintah ke IP server melalui internet. Kemudian dilakukan komunikasi serial raspbian yang ada di /dev/ttyUSBO. Melalui program aplikasi C maka akan mengirim perintah ke mikrokontroller untuk mematikan pin mikrokontroller. Begitu juga sebaliknya jika button Hidupkan di klik maka melalui komunikasi serial raspbian yang ada di /dev/ttyUSB0 akan menjalankan aplikasi $\mathrm{C}$ untuk mengirim perintah ke arduino agar supaya menghidupkan pin arduino. Halaman kontrol ditunjukkan pada gambar 3a :

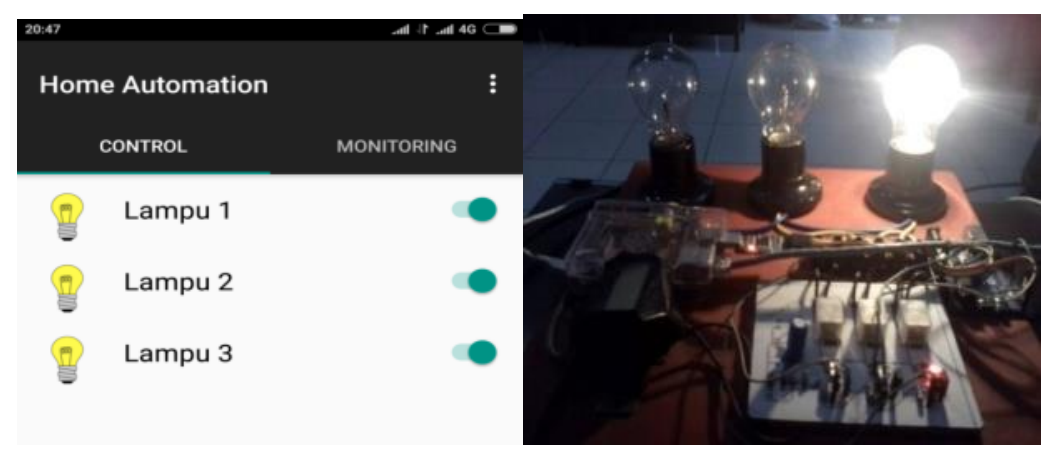

Gambar 3a. Halaman Utama 3b. Perangkat Keras

Jika button Hidupkan diklik maka warna indikator button akan berubah menjadi hijau dan sebagai penandanya warna lampu menjadi kuning. Sedangkan jika button di klik lagi maka otomatis akan berubah menjadi abu-abu yang menandakan bahwa button tidak diaktifkan.

Pada pengujian ON-OFF perangkat elektronik pada gambar $3 b$ telah diuji selama tiga kali dengan cara klik manual, beberapa hasilnya pada tabel 1. 
Tabel 1. Pengujian panel perangkat elektronik melalui klik manual

\begin{tabular}{lllll}
\hline No & Panel & Panel 1 & Panel 2 & Panel 3 \\
\hline 1 & Panel 1 Hidupkan & ON & OFF & OFF \\
2 & Panel 1 Matikan & OFF & OFF & OFF \\
3 & Panel 2 Hidupkan & OFF & ON & OFF \\
4 & Panel 2 Matikan & OFF & OFF & OFF \\
5 & Panel 3 Hidupkan & OFF & OFF & ON \\
6 & Panel 3 Matikan & OFF & OFF & OFF \\
\hline
\end{tabular}

Pada tabel 1 hasil pengujian menunjukkan hasil yang baik, yaitu sistem berjalan sebagai mana mestinya, yaitu apabila di klik Hidupkan maka perangkat elektronik akan ON dan apabila di klik Matikan maka perangkat elektronik akan OFF, hal ini berlaku untuk Panel 1, Panel 2, dan Panel 3.

Pengujian kedua yang dilakukan adalah Pengujian Respon Time, Pengujian respon time terhadap request dilakukan untuk mengetahui lama respon time sistem terhadap request dari pengguna. Mekanisme pengujian respon time yaitu dengan mengukur lama waktu pada saat mulai eksekusi perangkat elektronik on atau perangkat elektronik off. Pengujian respon time ini dilakukan selama 3 kali masing-masing untuk respon time saat eksekusi perangkat elektronik ON dan respon time saat eksekusi perangkat elektronik OFF manual. Ditunjukkan pada tabel 2.

Tabel 2. Pengujian respon time terhadap request saat klik manual

\begin{tabular}{llccc}
\hline No & Panel & $\begin{array}{c}\text { Respon Time 1 } \\
\text { (detik) }\end{array}$ & $\begin{array}{c}\text { Respon Time } \\
\text { 2 (detik) }\end{array}$ & $\begin{array}{c}\text { Respon Time } \\
\text { 3 (detik) }\end{array}$ \\
\hline 1 & Panel 1 Hidupkan & 1.32 & 1.32 & 1.30 \\
2 & Panel 1 Matikan & 1.26 & 1.24 & 1.28 \\
3 & Panel 2 Hidupkan & 1.21 & 1.24 & 1.23 \\
4 & Panel 2 Matikan & 1.23 & 1.27 & 1.26 \\
5 & Panel 3 Hidupkan & 1.30 & 1.29 & 1.29 \\
6 & Panel 3 Matikan & 1.26 & 1.28 & 1.31 \\
\hline
\end{tabular}

Pada tabel 2 beberapa hasil waktu respon sistem terhadap request. Pengujian tersebut dilakukan sebanyak tiga kali yaitu pengujian 1, pengujian 2, dan pengujian 3. Hasil waktu respon berbeda-beda, dari keadaan tersebut didapat waktu respon yang tertinggi pada pengujian 1 adalah saat lampu 1 dihidupkan dan terendah pada saat lampu 2 dihidupkan. Sedangkan pada pengujian 2 waktu respon yang tertinggi terjadi saat lampu 1 dinyalakan dan terendah pada saat lampu 1 dimatikan dan lampu 2 dihidupkan. Sedangkan pada pengujian ketiga waktu respon yang tinggi terjadi saat lampu 3 dimatikan dan waktu respon terendah saat lampu 2 dihidupkan. Sedangkan untuk rata-rata waktu respon dari ketiga pengujian diatas adalah 1,26 detik. Hasil tersebut menunjukkan bahwa respon sistem sudah dalam kondisi baik.

Terdapat dua sensor yang digunakan yaitu sensor cahaya dan sensor suhu. Sensor dapat digunakan untuk memonitor dan mengontrol perangkat elektronik secara otomatis. Dalam kasus ini sensor yang diintegrasikan adalah sensor cahaya. Sensor tersebut disetting jika cahaya gelap maka secara otomatis akan menghidupkan perangkat elektronik khususnya lampu, dan jika terang maka secara otomatis akan mematikan perangkat elektronik.

Pada pembacaan sensor cahaya range nilainya mulai dari 0 sampai dengan 1023 bit yang menunjukkan nilai intensitas cahayanya. Jika semakin tinggi nilai pembacaan sensor maka semakin terang intensitas cahayanya. Begitu juga sebaliknya jika semakin rendah nilai pembacaan sensor maka kondisi cahaya akan semakin gelap. untuk mempermudah pembacaan nilai maka dilakukan perubahan dari nilai pembacaan sensor menjadi nilai prosentase. Adapun penentuan nilai cahaya yang dihitung berdasarkan prosentase ditunjukkan pada persamaan 1 :

Nilai Prosentase $=\frac{1023-\text { Nilai Sensor }}{1023} \times 100 \%$

Sehingga didapat semakin tinggi prosentase maka kondisi ruangan akan semakin gelap dan sebaliknya semakin rendah prosentase maka akan semakin terang kondisi ruangan nya. Pada aplikasi ini ditentukan kondisi cahayanya untuk keperluan sistem otomatisasi perangkat elektronik. Jika terang maka perangkat elektronik khususnya lampu akan padam, dan jika gelap maka lampu akan menyala. Penentuan kondisi tersebut dapat dilihat pada tabel 3. 
Tabel 3. Penentuan kondisi cahaya ruangan

\begin{tabular}{llll}
\hline \multirow{2}{*}{ No } & \multicolumn{2}{c}{ Nilai Cahaya } & \multicolumn{1}{c}{$\begin{array}{c}\text { Kategori } \\
\text { Kondisi } \\
\text { Cahaya }\end{array}$} \\
\cline { 2 - 4 } & \multicolumn{1}{c}{ Sensor } & Prosentase & Terang \\
\hline 1 & $385-1023$ & $0-62 \%$ & Gelap \\
\hline
\end{tabular}

Penentuan nilai 385 didasarkan pada kalibrasi kondisi dengan kondisi ruangan sebenarnya. Dari hasil prosentase maka didapat 2 buah kategori kondisi cahaya yaitu gelap diantara $63-100 \%$ dan kondisi terang dengan prosentase intensitas cahaya $0-62 \%$. Sedangkan untuk pengujian sistem otomatisasi perangkat elektronik berdasarkan sensor cahaya dapat dilihat pada tabel 4.

Tabel 4. Pengujian sensor cahaya

\begin{tabular}{llll}
\hline \multirow{2}{*}{ No } & \multicolumn{2}{c}{ Nilai Cahaya } & \multirow{2}{*}{$\begin{array}{c}\text { Perangkat } \\
\text { Elektronik }\end{array}$} \\
\cline { 2 - 4 } & Sensor & Prosentase & \\
\hline 1 & $385-1023$ & $0-62 \%$ & OFF \\
2 & $0-455$ & $63-100 \%$ & ON \\
\hline
\end{tabular}

Pada pengujian sensor cahaya ini didapat bahwa sistem otomatisasi perangkat elektronik dapat berjalan dengan baik, karena sistem sudah berjalan sesuai dengan perintah yang diberikan.

Sedangkan untuk pengujian sensor suhu digunakan untuk sistem otomatisasi perangkat elektronik khususnya kipas. Pada pengujian ini juga ditentukan beberapa kondisi kapan waktu kipas menyala dan mati. Penentuan kategori kondisi suhu ruangan tersebut dapat dilihat pada tabel 5.

Tabel 5. Kategori kondisi suhu

\begin{tabular}{lll}
\hline No & Suhu & Kategori Suhu \\
\hline 1 & $0-23{ }^{0} \mathrm{C}$ & Dingin \\
2 & $23-27^{\circ} \mathrm{C}$ & Sedang \\
3 & $27-100^{\circ} \mathrm{C}$ & Panas \\
\hline
\end{tabular}

Sedangkan untuk pengujian sensor suhu dengan kipas dapat dilihat pada tabel 6. Pada tabel tersebut dibuat range suhu diantara $20{ }^{\circ} \mathrm{C}$ sampai dengan $34{ }^{\circ} \mathrm{C}$, dengan kenaikan $1{ }^{\circ} \mathrm{C}$, kemudian diuji dengan menggunakan kipas untuk menurunkan suhunya dan juga dengan menggunakan thermometer untuk menguji nilai pembacaan sensor dengan nilai pengukuran sebenarnya.

Tabel 6 Pengujian sensor suhu

\begin{tabular}{|c|c|c|c|c|c|}
\hline No & Suhu Termometer & Suhu Sensor & Selisih & Prosentase & Kipas \\
\hline 1 & $20^{\circ} \mathrm{C}$ & $20,2^{\circ} \mathrm{C}$ & $0,2^{\circ} \mathrm{C}$ & $1.0 \%$ & OFF \\
\hline 2 & $21{ }^{\circ} \mathrm{C}$ & $21,4{ }^{0} \mathrm{C}$ & $0,4{ }^{0} \mathrm{C}$ & $1.9 \%$ & OFF \\
\hline 3 & $22{ }^{\circ} \mathrm{C}$ & $22,8^{\circ} \mathrm{C}$ & $0,8^{\circ} \mathrm{C}$ & $3.6 \%$ & OFF \\
\hline 4 & $23{ }^{\circ} \mathrm{C}$ & $23,5^{\circ} \mathrm{C}$ & $0,5^{\circ} \mathrm{C}$ & $2.2 \%$ & ON \\
\hline 5 & $24{ }^{\circ} \mathrm{C}$ & $24{ }^{\circ} \mathrm{C}$ & $0{ }^{\circ} \mathrm{C}$ & $0.0 \%$ & ON \\
\hline 6 & $25^{\circ} \mathrm{C}$ & $25{ }^{\circ} \mathrm{C}$ & $0^{\circ} \mathrm{C}$ & $0.0 \%$ & $\mathrm{ON}$ \\
\hline 7 & $26{ }^{\circ} \mathrm{C}$ & $26,4{ }^{0} \mathrm{C}$ & $0,4{ }^{0} \mathrm{C}$ & $1.5 \%$ & ON \\
\hline 8 & $27{ }^{\circ} \mathrm{C}$ & $27,5^{\circ} \mathrm{C}$ & $0,5^{\circ} \mathrm{C}$ & $1.9 \%$ & ON \\
\hline 9 & $28{ }^{\circ} \mathrm{C}$ & $28,4{ }^{\circ} \mathrm{C}$ & $0,4^{0} \mathrm{C}$ & $1.4 \%$ & ON \\
\hline 10 & $29{ }^{\circ} \mathrm{C}$ & $29{ }^{\circ} \mathrm{C}$ & $0{ }^{\circ} \mathrm{C}$ & $0.0 \%$ & ON \\
\hline 11 & $30{ }^{\circ} \mathrm{C}$ & $30,5^{\circ} \mathrm{C}$ & $0,5^{\circ} \mathrm{C}$ & $1.7 \%$ & $\mathrm{ON}$ \\
\hline 12 & $31{ }^{\circ} \mathrm{C}$ & $31,8^{\circ} \mathrm{C}$ & $0,8^{0} \mathrm{C}$ & $2.6 \%$ & ON \\
\hline 13 & $32{ }^{\circ} \mathrm{C}$ & $32,6{ }^{\circ} \mathrm{C}$ & $0,6^{0} \mathrm{C}$ & $1.9 \%$ & ON \\
\hline 14 & $33{ }^{\circ} \mathrm{C}$ & $34,6{ }^{\circ} \mathrm{C}$ & $0,6^{0} \mathrm{C}$ & $1.8 \%$ & ON \\
\hline 15 & $34{ }^{\circ} \mathrm{C}$ & $35,6{ }^{\circ} \mathrm{C}$ & $0,6{ }^{\circ} \mathrm{C}$ & $1.8 \%$ & $\mathrm{ON}$ \\
\hline \multicolumn{3}{|c|}{ Rata - Rata } & $0,4^{0} \mathrm{C}$ & $1,5 \%$ & \\
\hline
\end{tabular}


Pada tabel 6 didapat bahwa untuk pengujian suhu ruangan dibandingkan antara suhu thermometer dengan suhu pembacaan sensor, hasilnya terdapat beberapa perbedaan antara nilai thermometer dengan nilai sensor, rata-rata selisihnya adalah $0,4{ }^{\circ} \mathrm{C}$, dan kemudian nilai prosentase selisihnya dihitung dengan menggunakan persamaan 2:

Prosentase $=\frac{\text { Suhu Sensor-Suhu Termometer }}{\text { Suhu Termometer }} \times 100 \%$

Dari hasil perhitungan didapat rata-rata prosentase selisih adalah 1,5\%. Hasil ini menunjukkan bahwa sensor suhu telah bekerja dengan baik dengan tingkat ketelitian yang sangat baik juga. Kemudian untuk pengujian suhu dengan kipas, hasilnya kipas bekerja sesuai dengan yang diinginkan yaitu pada suhu kurang dari $23{ }^{\circ} \mathrm{C}$ kipas mati, dan suhu diatas $23{ }^{\circ} \mathrm{C}$ maka kipas akan menyala.

\section{KESIMPULAN}

Hasil penelitian ini berupa sistem otomatisasi perangkat elektronik rumah yang bisa dimanfaatkan untuk sistem kontrol serta monitor lampu secara manual maupun secara otomatis dengan sensor, User interface yang digunakan adalah dengan menggunakan Android, sistem dapat berjalan secara manual maupun otomatis dengan menggunakan sensor. Rata-rata respon sistem terhadap setiap permintaan perintah adalah sebesar 1,26 detik, dan nilai error pembacaan sensornya rata-rata adalah 1,5\%.

\section{DAFTAR PUSTAKA}

[1] Mario C, Gianfranco S \& Giovanni Pau, "A Priority-Based CSMA/CA Mechanism to Support Deadline-Aware Scheduling in Home automation Applications Using IEEE 802.15.4”. Research Article. International Journal of Distributed Sensor Network. Italy. 2013

[2] Dias P, dkk, (2013). "Pengembangan Perangkat Lunak Gateway untuk Home automation Berbasis IQRF TR53B Menggunakan Konsep CGI”, SESINDO 2013.

[3] Farid A, Wahyu, A. S, and Maman, S. "Perancangan Prototype Web-Based Online Smart Home Controlled By Smartphone”. Jurnal Teknik Elektro UNDIP. 2015.

[4] D. M. Han and J. H. Lim, "Smart home energi management system using IEEE 802.15.4 and ZigBee, ”IEEE Transactions on Consumer Electronics, vol. 56, no. 3, pp. 1403-1410, 2010.

[5] Y.-P. Tsou, J.-W. Hsieh, C.-T. Lin, and C.-Y. Chen, "Building A Remote Supervisory Control Network System For Smart home Applications," in Proceedings of the IEEE International Conference on Systems, Man and Cybernetics ((SMC '06),vol.3,pp. 1826-1830, October 2006.

[6] A.J.Bernheim Brush, Bongshin Lee, Ratul M, Sharad A, Stefan S, and Colin D. "Home automation In The Wild : Challenges and Opportunities". Microsoft Research. University of Washington. ACM. 2011.

[7] Carelin Felix and Jacob. R, "Home automation Using GSM". In proceedings of international conference on signal processing, comunication, computing and network technologies. ICSCCN. 2011.

[8] R.Piyare and M.Tazil, “Bluetooth Based Home automation System Using Cell Phone”, 2011 IEEE 15th International Symposium on Consumer Electronics.

[9] Iyuditya and Erlina Dayanti, "Sistem Pengendali Lampu Ruangan Secara Otomatis Menggunakan Pc Berbasis Mikrokontroler Arduino Uno”, Jurnal Online ICT STMIK IKMI-Vol.10-Edisi Desember 2013. 
Jurnal SIMETRIS, Vol. 9 No. 1 April 2018

ISSN: 2252-4983

[10] Sri Supatmi,Taufiq Nuzwir Nizar,and Reza Fahlevi, "Sistem Kontrol Peralatan Rumah dan Monitoring Kondisi Rumah Melalui Internet Berbasis Web dan OpenWRT", Jurnal Teknik Komputer Unikom-Komputika-Volume 3, No.2-2014 